\title{
NOTES ON THE STRUCTURE AND HABITS OF THE WOLFFISHES.
}

\author{
By Theodore Gill, \\ Associate in Zoology, U. S. National Museum.
}

\section{INTRODUCTION.}

In order to be able to appreciate the influence of structure on the habits of the wolffishes, the writer undertook the examination of the specimens preserved in the U.S. National Museum and was surprised to find the range of variation revealed through the examination of the skeletons. As in many other cases, the relations of the species to each other can not be understood without a comparative examination of the inner structure. The head curator of biology of the Museum, Dr. F. W. True, kindly had what were supposed to be unique specimens of different species skeletonized, and they proved to be of species decidedly different from those they were believed to represent and to be undescribed. Further, the manner in which previously described species had been arranged in dichotomous synopses was found to be quite unnatural and contradicted by the skeletal characters. The facts in the case are set forth in the following article.

\section{PART 1.}

\section{THE STRUCTURAL CHARACTERISTICS OF THE ANARRHICHADOID GENERA.}

The wolffishes have been regarded as pertinents of the family of Blenniids by most authors, but in 1865 Gill proposed an independent one (Anarrhichadidæ) for them, and that view has since been generally adopted in the United States and by a few in Europe, especially F. A. Smitt in his Scandinavian Fishes. The Swedish naturalist has based the family chiefly on the dentition, describing the "jaw and palatine teeth of extraordinary strength, partly obtuse molars (on the vomer and palatine bones and in the lower jaw), partly conical or curved canines on the intermaxillary bones in the front part-sometimes in the back part as well - of the lower jaw." These characters, however, are of generic rather than family value. The most important distinc- 
tion between the Anarrhichadids and Blenniids are manifest in the scapular arch (especially the suprascapula), the actinosts, and the absence of ventral fins.

The family may be defined as follows:

\section{Family ANARRHICHADIDA.}

SYNONYMS AS FAMILY.

Anarrhichadaidæ (misprint) GiLl, Can. Nat., (2), vol. 2, 1865, pp. 247, 252.

Anarrhichaddæ GILl, Arr. fam. Fishes, 1872, p. 4.

Anarrihichæ Fitzinger Sitzungsber. k. Akad. Wiss., Berlin, vol. 67, abth. 1., 1873, p. 43.

Anarrhichadidæ Smitt, Scand. Fishes, pt. 1, 1892, p. 231.

Anarhichadidæ Jordan and Evermann, Fishes North and Middle Amer., pt. 3, 1898, pp. 2343, 2445.

Gobioides, part, Cuvier, Zoarcidx, part, SwaInson,

Blennïdæ, part, GüNTHER and others.

\section{SYNONYMS AS SUBFAMILY ANARRHICHADINÆ.}

Anarrhichæformes Bleeker, Enum. sp. Piscium Arch. Ind., 1859, p. xxv. Anarrhichaninæ (misprint) GILL, Cat. Fishes North Amer., 1861, p. 46.

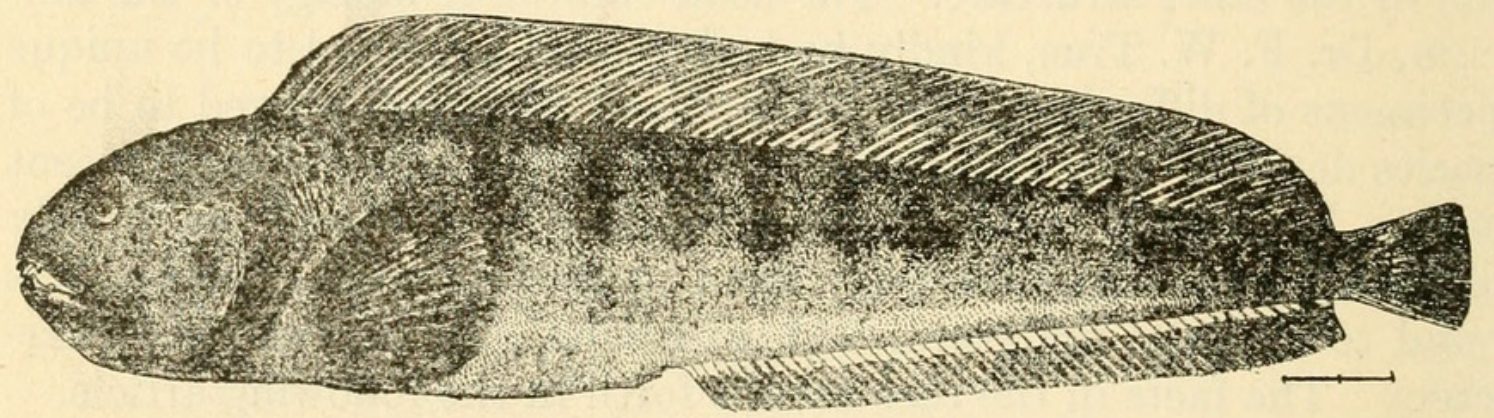

Fig. 1.-Anarrhichas lupus.

Anarrhichadinæ Jordan and Gilbert, Syn. Fishes North Amer., 1882, p. 755.

Anarrhichadinæ Jordan and Evermann, Fishes North and Middle Amer., pt. 3, 1898, p. 2445.

SYNONYM AS SUBFAMILY ANARRHICHTHYINA.

Anarrhichthyinz. Jordan and Evermann, Fishes North and Middle Amer., pt. 3, 1898 , p. 2445.

Blennioidean fishes of a more or less elongated form without ventral fins, with the head decurved around the snout, mouth deeply and obliquely cleit, intermaxillaries abutting on and attached to front of ethmoid, teeth on jaws, vomer and palatine bones attypically crowded and molariform, the main ones of the lower jaw acrodont, others external, dorsal with inarticulate rays or spines; cranium without a myodome, attypically compressed behind eyes, and with the occipital region declivous backward; suborbital semiring narrow and with a slight ophthalmophorous shelf; suprascapula simple (not forked), hypercoracoid and hypocoracoid separated by membrane-like carti- 
lage and the former perforated near base; four actinosts squarish, uppermost behind hypercoracoid and smallest, lowermost behind hypocoracoid, intervening second and third behind membrane; pectoral rays all connected with actinosts; pelvis V-shaped, with its free limb decurved and its anterior limbs applied to inner faces of cœnostea and reaching forward to the crests; abdominal vertebræ (except foremost two) with transverse processes or parapophyses with which the ribs are connected.

The teeth of the lower jaw are acrodont in that the main series is borne on the ridges of the dentaries, but, in addition to the main row, one or more others may be developed, and in such cases the outer sides of the bones are more or less inflected. In the common wolffish ( $A n$ arrhichas lupus) in which the multiplication and enlargement of the teeth are carried to a maximum, the inflection is manifest to such an extent that the dentigerous area actually slopes inward and downward. In Lycichthys paucidens, whose lowerlateral teeth are uniserial, the inflection is scarcely noticeable. In Anarrhichthys a somewhat intermediate condition is manifest, although the dentition is much more like that of Anarrhichas than of Lycichthys.

In brief the family is composed of a few large fishes with

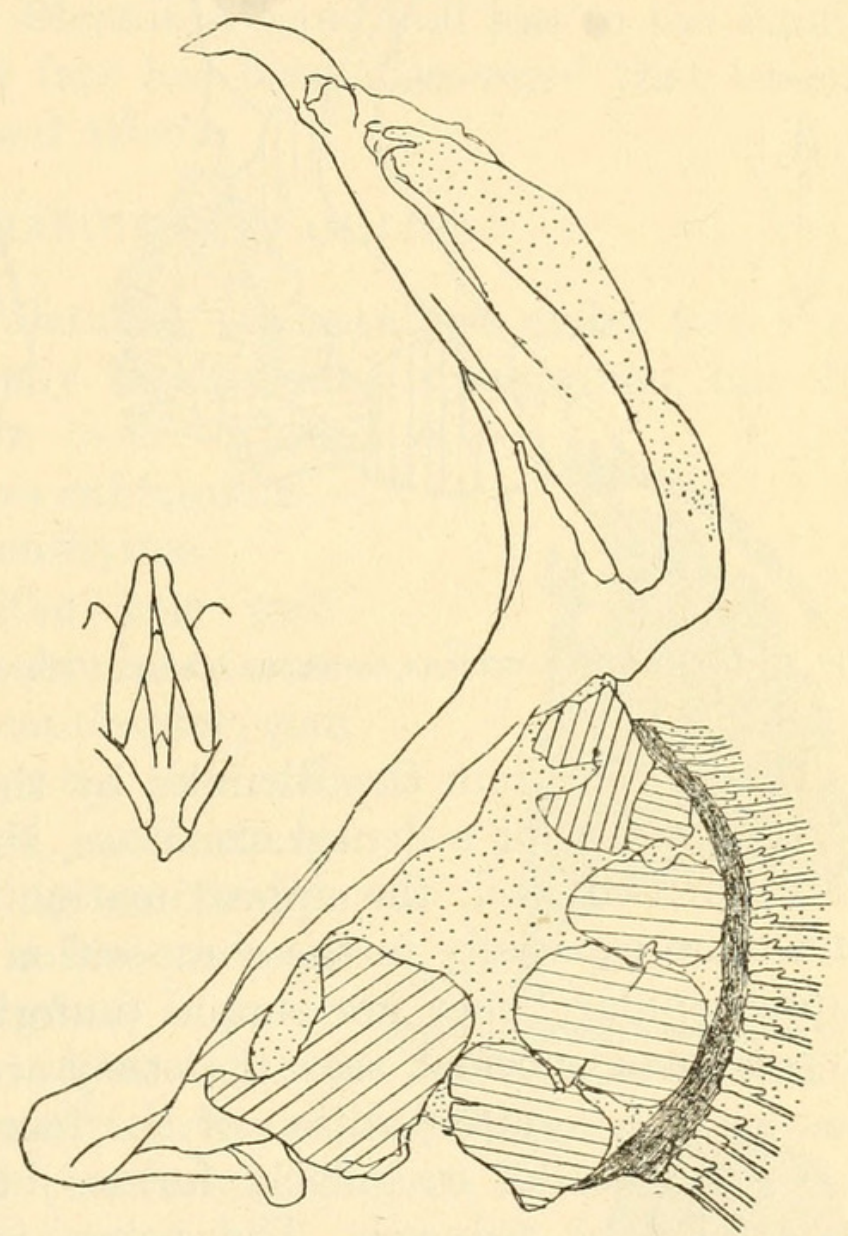

Fig. 2.-ANARrhichas LUPUS, SHOULDER GirdLE. unmistakable characters and physiognomy. The body is more or less elongated and covered with rudimentary scales, or naked, the head decurved around the snout, the mouth moderately deep and oblique; the dentition in the typical forms is quite characteristic, the front jawteeth being canine-like, the vomerine and palatine more or less thick and molariform, and the lateral mandibular molariform or blunt; the branchial apertures are confined to the sides; the dorsal fin is composed entirely of inarticulate rays or spines but is manifest under two distinct modifications; ventral fins are entirely absent in all.

Such are the principal superficial characters which distinguish the wolffishes, but better indications of relationship and differential char- 
acters are furnished by the skeleton. The abdominal vertebræ (except the first two) have robust transverse processes to which the ribs are attached; the cranium is more or less compressed behind the orbits, the occipital region is declivous backward, and the intermaxillaries connect by close suture with the ethmoid as in the Blennies.

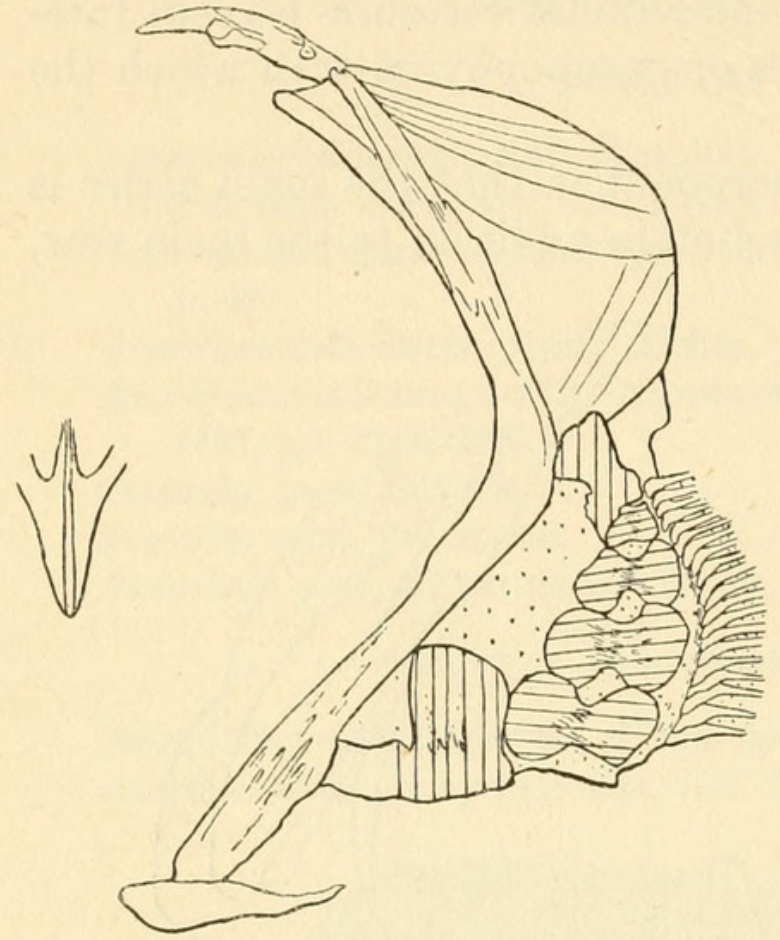

Fig. 3.-LycichthyS PAUCIDENS, SHOULDER GIRDLE.

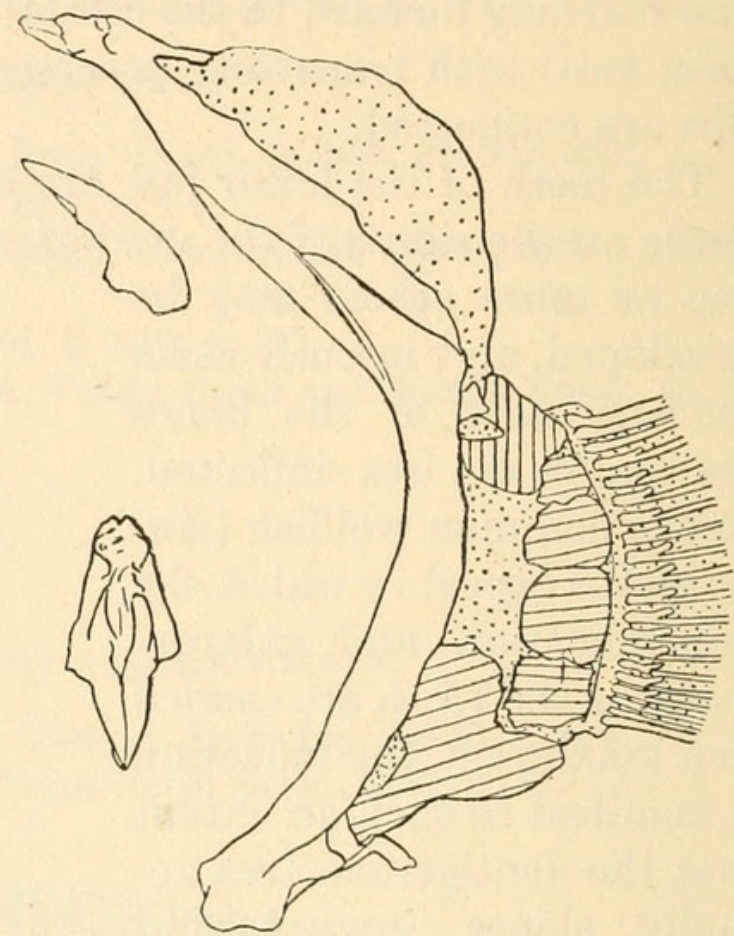

Fig. 4.-ANARRHichthys OCELlatus, SHOULDER GIRDLE.

They differ from the Blennies by the dentition, the enlargement of the vomer for a dental armature, the extension downwards of a parasphenoid keel, the approximation of the exoccipital condyles, and more especially in the composition of the shoulder-girdle. The suprascapular bones are simple (unforked); the hypercoracoid and hypocoracoid normal, save that they are small and separated by the

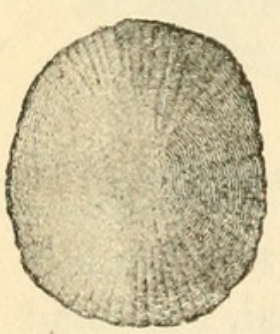

Fig. 5.-LYCICHTHYS

SCALE, AFTER

THORNAM (GAIM ARD). interposition of the four actinosts which are squarish or irregularly formed; the uppermost one is much reduced. The pelvis is represented by a Y-shaped piece whose limbs are foremost, lie on the upper surface of the cœnosteon, and connect with the anterior ridges of the latter. ${ }^{a}$

The genera have been combined by Doctor Boulenger (as well as by most other European ichthyologists) with the Blenniidæ under that family name, although he has attributed to the family a suprascapula or "posttemporal forked" and "hour-glass-shaped pterygials" or actinosts. These attributes are certainly not manifest in any of the Anarrhichadids and must have been assumed for them in consequence of the previous assumption of their close relationship to the Blenniids.

a Skeletons of Anarrhichas lupus, Lycichthys denticulatus, and Anarrhichthys ocellatus are before me. 


\section{PALEONTOLOGY OF ANARRHICHADIDS.}

The paleontological history of the wolffishes is practically unknown. From the Pliocene Coralline crag of England (Gedgrave in Suffolk) a tooth was obtained which was supposed by E. T. Newton (1891) to be derived from the Anarrhichas lupus. This is the only fossil that has been recorded. Cranial remains of a cretaceous fish (London clay) named Laparus alticeps by Agassiz (1844) were supposed by that ichthyologist to be related to Anarrhichas, but according to Woodward (1901) "they exhibit too many differences to be definitely ascribed to the family Blenniidæ" and still less to the family Anarrhichadidx. Nothing in fact has been discovered that lessens the gap between the family and others.

\section{ANARRHICHADOID SUBFAMILIES.}

The characteristics above detailed are manifest under two very distinct types so far as the body (cauditrunk) is concerned, but the head is essentially similar in both. These types may be distinguished as subfamiliesAnarrhichadinæ and Anarrhichthyinæ.

In the Anarrhichadinæ (the true wolffishes) the body is robust behind and contrasts with almost all other acanthopterygian fishes in that in the wolffishes the hindmost spines are abbreviated, rigid, and sharppointed, while all the preceding are flexible at their tips; the caudal fin is free and normally developed. Only one genus is generally recognized-Anarrhichas. A second very

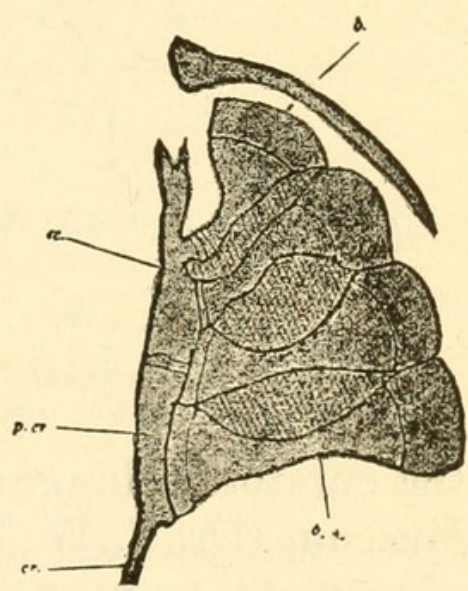

Fig.6.-BLENNIUS PHOLIS, SHOULDER GIRDLE (AFTER PARKER). distinct one (Lycichthys) is, however, represented by the A. latifrons. In another group for which unfortunately we have to use the barbarous name Anarrhichthyines (which may be designated in English as wolf-eels), the body is attenuated backwards and eel-like, and the dorsal, as well as anal, is united with the caudal fin; all the dorsal spines are flexible. The only genus, Anarrhichthys, is known from a single species, $A$. ocellatus or the wolf-eel.

\section{ANARRHICHADOID GENERA.}

The Anarrhichadines have been referred by all authors to one genus, Anarrhichas, although two of the four species formerly referred to it were distributed among two subgenera more than a quarter century ago.

Proc.N.M.vol.39-10-13 
In 1877, Gill, in Baird's Annual Record of Science and Industry for 1876 (p. clxvii), noticed Steenstrup's then recently published monograph on Anarrhichas, and concluded with the statement that "in the extreme northern seas, and especially the Greenland waters, no less than four species [of Anarrhichadids] are found, which represent

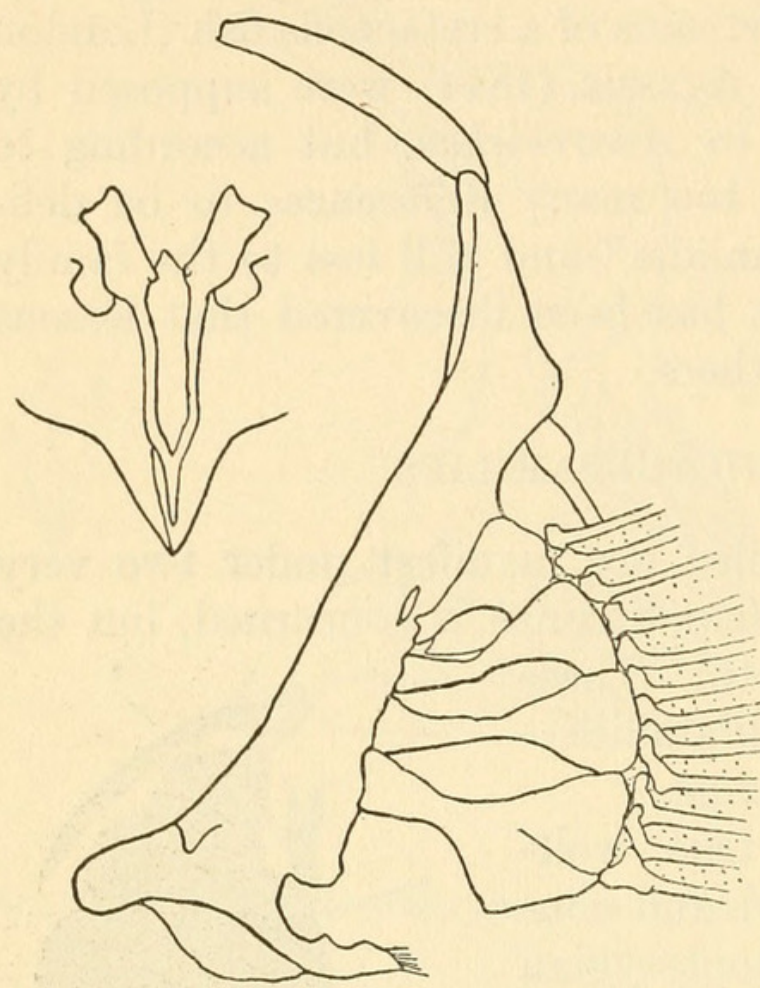

Fig. 7.-BLENNIUS OCELLARIS, SHOULDER GIRDLE. two quite distinct types or subgenera, one (Anarrhichas proper) containing two species (A. lupus and $A$. minor), and the other (Lycichthys) containing also two, but less known species (A. latifrons and $A$. denticulatus)."

This suggestion has been completely overlooked by all subsequent writers and Jordan and Evermann have even associated A. latifrons with $A$. minor in a section $(a b)$ contrasted with one $\left(\begin{array}{lll}a & b & b\end{array}\right)$ including $A$. lupus, and all those in a primary section (a) contrasted with another (a a) including $A$. lepturus and $A$. orientalis.

In view of such discrepancy the present author appealed to the curator in charge of the biological department of the U.S. National Museum (Dr. F. W. True) to have skeletons made of representatives of each of the genera. This has been done and the differences between Anarrhichas as restricted and Lycichthys proved to be far greater than were expected. The principal ones are here contrasted in parallel columns.

ANARRHICHAS.

\section{Teeth}

more or less blunt;

I mostly acute or subacute;

\section{Intermaxillary}

very robust, nearly straight, about 6 in an rather slender, curved, 4 to 8 in an outer outer row, small and irregular in an inner row, and a few intervening between rows;

\section{Mandibular}

4 large in front with blunt summits; crowded and molar on sides; the ridge of the dentary inflected and with largest teeth, the outer on the inflected sides and smaller;
LYCICHTHYS.

4 to 8 slightly enlarged in front, curved and with subacute summits; well separated acute and biserial or uniserial on sides; those of inner row sometimes molar; the dentary ridge scarcely infiected; row, smaller (6-12) in an inner row; 


\section{Vomerine}

in a wide patch longer than palatine, | in small patch much shorter than palatine, molar and closely crowded, in 2 rows in some species subacute and well sepaand intervening smaller teeth; rated; in others molar and closely crowded;

\section{Palatine}

molar, crowded and biserial;

subacute, well separated and biserial; in some bluntish in inner row;

\section{Hypopharyngeal teeth}

subequal in a broad band;

enlarged in an inner row and a few scattered outside;

\section{Branchiostegal rays}

8,4 slender to inferior edge of ceratohyal, 2 stout to hinder edge of ceratohyal, and 2 stout in depressed lower half of epihyal ( 8 arranged in 2 groups of 4 each, 4 slender with insertions internal, and 4 stout with insertions external);

\section{Ossification}

complete.

| incomplete, the appearance sponge-like.

Cranial axis

angular, the vomer subtending a high an- $\mid$ nearly rectilinear, the vomer being on the gle with the parasphenoid.

\section{Parasphenoid}

much compressed, very narrow in front $\mid$ rather wide and expanded sideward in of cerebral chamber. front of cerebral chamber.

\section{Postfrontal region}

much compressed and very narrow | rather depressed and broad between in(pinched) between interorbital region terorbital region and supraoccipital.

and supraoccipital.

\section{Sphenotic and parietal}

separated by a large deep pit circum- separated only by regular suture and scribed by the approximation of the bones before and behind.

\section{Suprascapula}

undivided and prolonged forward over $\mid$ undivided and attached to the inner surthe sphenotic-parietal pit, and con- face of the periotic ridge. nected with the ridge in front and clamped behind by the approximated sphenotic and parietal.

\section{Actinosts}

(two and three) not or little constricted (two and three) much contracted at at middle. middle. 
These contrasted characteristics are merely the most salient or obvious of the many that confront the observer; ${ }^{a}$ they are assuredly enough to certify to the generic distinction between Anarrhichas and Lycichthys. In fact, in most respects the cranial and scapular differences between the genera in question are not only more obvious but of greater taxonomic importance than those between Anarrhichas and Anarrhichthys. Further, the distinction between the last two genera, based on the relative length and size of the tail has been exaggerated. The caudal fin of Anarrhichthys is of the same type as that of Anarrhichas and merely reduced in size.

The relations and most important, or rather most easily ascertained diagnostic peculiarities of the three genera of the family are now indicated.

ANALYTICAL CHARACTERS.

Key to genera of Anarrhichadids.

$a^{1}$. Body moderately elongated and robust backward and vertebræ moderately numerous (74-81, e. g. $26+50 \mathrm{pm}$.); dorsal and anal with a moderate number of rays;

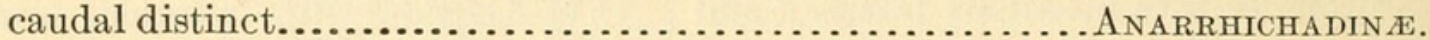

$b^{1}$. Teeth mostly subacutc and not crowded; vomerine patch rather short (not extending as far back as palatine patches); cranium flattened behind interorbital area; cranial axis almost rectilinear; branchiostegal rays 7 .. Lycichthys.

$b^{2}$. Teeth chiefly blunt, or molarand crowded; vomerine patch elongated (extending backward beyond palatine patches); cranium pinched behind interorbital area; cranial axis highly angulated by the extension downward of the vomer;

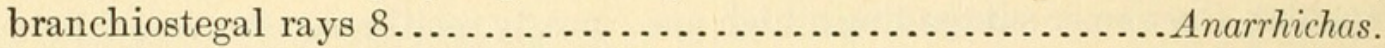

$a^{2}$. Body greatly elongated and attenuated backward and vertebræ extremely numerous (e.g. $350=38+212 \mathrm{pm}$.); dorsal and anal with corresponding number of rays (D. 250 ; A. 230 pm.); caudal connected with dorsal and anal..............

ANARRHICHTHYINE.

Teeth blunt, or molar and crowded, vomerine patch elongated; cranial axis moderately angulated ............................... Anarhichthys.

The primary groups of the family - the subfamilies - are sufficiently defined here, and clearness of conception of their differences would be marred rather than enlarged by the few coordinated characters, so relatively unimportant are they. The genera, however, are so distinct that their characteristics are numerous, as will appear by a comparison of those now to be given.

The genera are considered in the order of their assumed development, the most generalized first, the most specialized last.

$a$ Among other notable differences between the genera are those manifested between the dorsal rays signalized by Steenstrup and Collett. 


\section{Genus LYCICHTHYS.}

Lycichthys GILL, Ann. Rec. Sci. and Ind. 1876, 1877, p. clxvii. Anarrhichas, sp. auct. pl.

Type.-Anarrhichas latifrons Steenstrup.

Anarrhichadids with a moderately elongated body, rudimentary scales, dorsal fin regularly elevated and with its hindmost spines especially stiffened.

Teeth acute or subacute; intermaxillary rather slender, curved and about 4 in an outer row, smaller (about 6 ) in an inner row; mandibular 4 to 6 slightly enlarged in front, curved and with subacute summits; well separated, acute and biserial or uniserial on sides; the dentary ridge not inflected; vomerine in small patch much shorter than palatine, subacute and well separated; palatine subacute, well separated and biserial.

Hypopharyngeal teeth enlarged in an inner row and a few scattered outside.

Branchiostegal rays 7, 4 to inferior edge of ceratohyal, 1 to hinder angle of ceratohyal and 2 to surface of epihyal near lower edge.

Ossification incomplete, the appearance sponge-like.

Cranial axis nearly rectilinear, the vomer being on the same line as the parasphenoid.

Parasphenoid rather wide and expanded sideward in front of cerebral chamber.

Postfrontal region rather depressed and broad between interorbital region and supraoccipital.

Sphenotic and parietal bones separated only by regular suture and meeting in a ridge.

Suprascapula undivided and attached to the inner surface of the periotic ridge.

Actinosts (2 and 3) much contracted at middle.

The genus thus defined is confined to the deep cold seas of the Northern Hemisphere and has apparently four very distinct species exhibiting quite a remarkable range of dental variation, so great indeed as to call for the differentiation of one of them from the others to represent a peculiar group, were we to adopt for this genus the principles in vogue for most others.

The relative differences of the species, so far as regards dental characters, are indicated in the following dichotomous table:

Key to species of Lycichthys. ${ }^{a}$

$a^{1}$. Mandibular teeth biserial; palatine and intermaxillary teeth numerous.

$b^{1}$. Vomerine teeth enlarged and crowded.

$c^{1}$. Vomerine teeth much enlarged and with flattened crowns, 7 or thereabouts, palatine teeth of outer row (about 6-7) erect, elongated and conic; of inner

$a$ I hope later to be able to go into more detail respecting the species of Lycichthys. 
row (about 5-6) inclined inward, short and blunt; large intermaxillary teeth in outer row 6 ; smaller in inner row $10-12 \ldots \ldots \ldots \ldots$. . fortidens.

$c^{2}$. Vomerine teeth little enlarged with mammiform crowns, 10 or thereabouts; palatine teeth weaker than in $L$. fortidens (about 8-9).....L. latifrons.

$b^{2}$. Vomerine teeth scarcely enlarged and in two rows, separated by an elliptical interval; palatine teeth of outer row (about 7) much stronger than those of

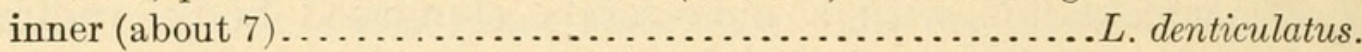
$a^{2}$. Mandibular teeth uniserial (9-10), palatine and intermaxillary teeth few.

Vomerine teeth few and subacute (about 5); palatine teeth of outer row (about $5-8$ ) erect but curved, scarcely if any larger than those of inner (about 4-6) which are suberect; intermaxillary teeth in outer row $4(2+2)$ in inner row

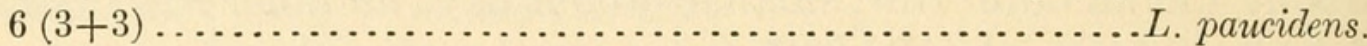

Great as these differences are, in view of the range of variation manifest in the related genus Anarrhichas, it is not impossible that they may intergrade and prove to be merely individual characteristics within a single species. It would, however, be too violent a strain on our present knowledge to anticipate such a result and the variants are allowed provisional specific rank. Besides, it would scarcely be expected that in a type like Lycichthys, in which the teeth are not crowded, the teeth would be as irregular as in Anarrhichas, in which the irregularity is to a great extent the consequence of crowding. If, indeed, we were guided by the example of students of other group, a distinct genus might be considered called for on account of the form named $L$. paucidens distinguished by uniserial mandibular teeth while the others have biserial teeth.

According to Goode and Bean " "many specimens [of Lycichthys] have been received from the halibut schooners," presumably from "the deep waters in 200 to 400 fathoms on the offshore banks," but unfortunately none except the two herein noticed have been preserved. $^{b}$ It is much to be hoped that other specimens may be received to enable us to understand the nature and value of the differential characters in question. So far as known, there are no external differences coincident with the dental, and consequently suspicion of the taxonomic significance of the latter may be entertained until confirmed or refuted.

\section{LYCICHTHYS FORTIDENS, new species.}

Anarrhichas latifrons Goode and BeAn, Oceanic Ichthyology, 1895, p. 301, fig. 271.

North Atlantic, in deep water, off the coasts of Maine and Nova Scotia.

Type 21845 Banquereau obtained at a depth of 300 fathoms by a Gloucester fishing vessel, the Marion.

$a$ Oceanic Ichthyology, p. 302.

$b$ The specimen figured and subsequently made into a cast appears not to have been preserved; it was 21373 of the collection. 
Full measurements of the specimen compared with Collett's measırements of a West Finmark specimen named latifrons are given by Goode.

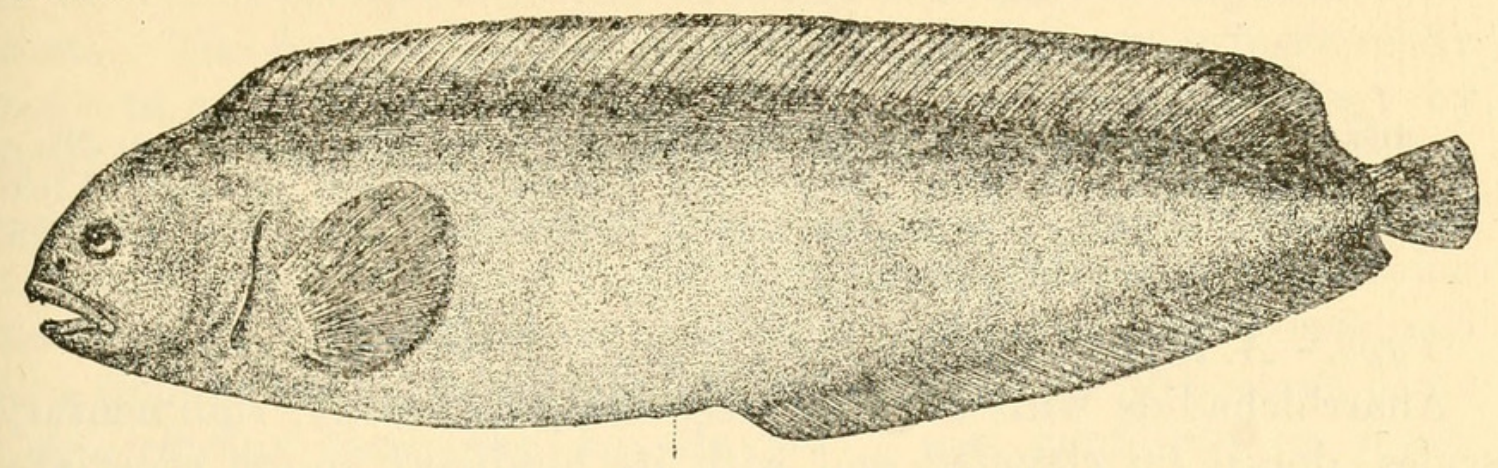

Fig. 8.-LYCichthYS FORTIDENS.

LYCICHTHYS LATIFRONS.

Anarrhichas latifrons Steenstrup and Hallgrimsson, Förh. Skand. Naturf. 1842 , p. 647.

North Atlantic (Iceland and Western Greenland, according to Steenstrup).

\section{LYCICHTHYS DENTICULATUS.}

Anarrhichas denticulatus Krфyer, Overs. Vid. Selsk. Kjøb., 1844, p. 140-GaImARD Voyage en Scand., en Lapponie, etc., Atlas, pl. 12, fig. 1.

Anarrhichas latifrons, part, Smitt, Jordan and Evermann.

North Atlantic (Western Greenland), in deep water.

LYCICHTHYS PAUCIDENS.

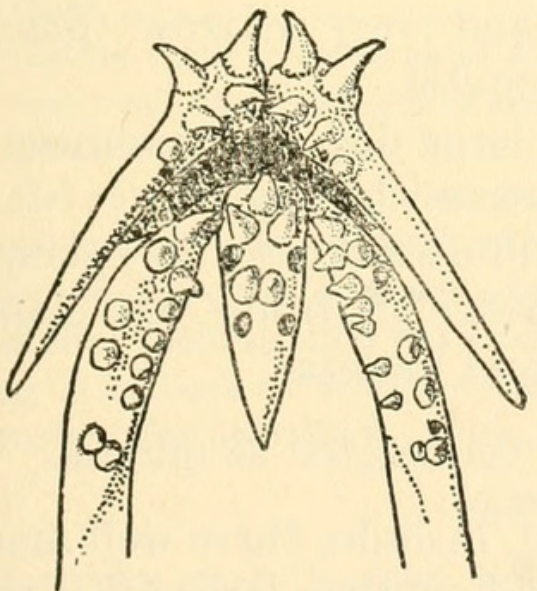

Fig. 9.-LYCichthYS PAUCIDENS, UPPER TEETH.

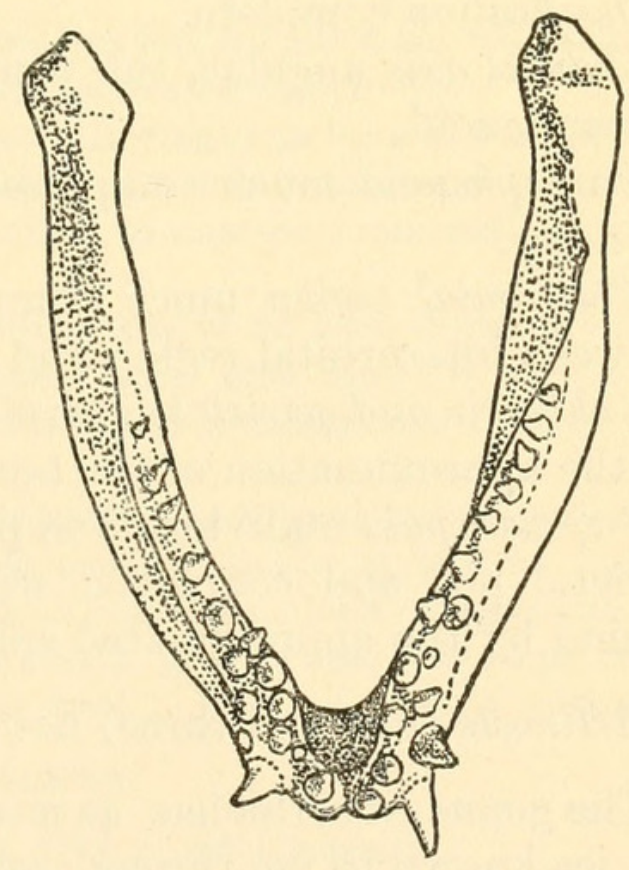

Fig. 10.-LYCICHTHYS PAUCIDENS, MANDIB* ULAR TEETH.

Lycichthys paucidens GiLL, Bull. Biol. Soc. Wash., Dec. 9, 1905, vol. 18, p. 251.

(Banquereau near Nova Scotia.)

North Atlantic, in deep water, off the coast of Maine and Nova Scotia. 
(Type 23915 Banquereau obtained at a depth of 200 fathoms September, 1879, by the Gloucester fishing vessel Marion, Capt. Philip Merchant.-Skull 467.)

\section{Genus ANARRHICHAS.}

Anarrhichas (Gesner) Linneus, Syst. Nat., 10th ed., 1758, vol. 1, p. 247.Steenstrup, Vid. Medd. Naturf. For. Kjøbenhavn, 1876, pp. 159-292 (extended to include $A$. latifrons and A. denticulatus).-GiLl, Ann. Rec. Sci. and Ind., 1876, 1877, p. clxvii.

Type.-A. lupus Linnæus.

Anarrhichadids with a moderately elongated body, rudimentary scales, dorsal fin elevated and with its hindmost spines especially stiffened.

Teeth more or less blunt; intermaxillary very robust, nearly straight, and about 6 in an outer row, small and irregular in an inner row, and a few intervening between rows; mandibular 4 large in front with blunt summits; crowded and molar on sides; the ridge of the dentary inflected and with largest teeth, the outer on the inflected sides and smaller; vomerine in a wide patch longer than palatine, molar and closely crowded, in 2 rows and intervening smaller teeth; palatine molar, crowded and biserial.

Hypopharyngeal teeth subequal in a broad band.

Branchiostegal rays 8, 4 to inferior edge of ceratohyal, 2 to hinder edge of ceratohyal and 2 in depressed lower half of epihyal.

Ossification complete.

Cranial axis angular, the vomer subtending a high angle with the parasphenoid.

Parasphenoid much compressed, very narrow in front of cerebral chamber.

Postfrontal region much compressed and very narrow (pinched) between interorbital region and superoccipital.

Sphenotic and parietal separated by a large deep pit circumscribed by the approximation of the bones before and behind.

Suprascapula undivided and prolonged forward over the sphenoticparietal pit, and connected with the ridge in front and clamped behind by the approximated sphenotic and parietal.

Actinosts (two and three) not or little constricted at middle.

The genus Anarrhichas, as now limited, includes three well-marked species known to me through autopsy and another (orientalis) which can not be identified with the only one seen by me (lepturus) occurring within essentially the same geographical range. The measurements attributed to the $A$. orientalis by Pallas are, however, irreconcilable with the form typical of the genus.

There is either a remarkable range of variation in the dentition of species of the genus or more than one have been confounded under 
the names $A$. lupus and $A$. minor. The peculiarities manifested by examples of species examined by the writer are collated in the following table, but probably will not be found to be fully exemplified in all others. The Scotch and Scandinavian naturalists, who have ready access to many specimens, would confer a favor on ichthyology by instituting a systematic comparison. A few of the variations manifest are illustrated in the accompanying figures. Every individual examined has been found to be peculiar, no two specimens being exactly alike. Nevertheless, American specimens were considered for a time to belong to an independent species. A distinctive name ("Anarrhichas vomerinus Agassiz Ms.") was conferred on it by D. H. Storer in 1855 , but the only character given was based on the vomerine dentition - "Vomerine teeth perfectly united together, forming a solid mass;" it was only added that "Mr. Agassiz considers this a distinct species from the European, basing his opinion upon a difference in the number and disposition of the vomerine tubercles." It is probable that Storer did not mean what he said; it is unlikely that he could have seen a specimen with teeth "forming a solid mass." The teeth are conglomerated into a compact area, but the interspaces of the separate teeth are evident, however narrow they may be. No distinctive characteristic has been found between American and European representatives of the genus.

Key to species of Anarrhichas.

$a^{1}$. Dorsal spines $62-77$; vomerine teeth not extending forward much beyond palatine (by only 1 pair), all bluntly molar; palatine teeth all molar crowns.

$b^{1}$. Palatine teeth in moderately long patches (extending as far back as front of last vomerine teeth), those of outer row little larger than inner; color yellowish or grayish blue, on back and sides manifest in numerous roundish blackish

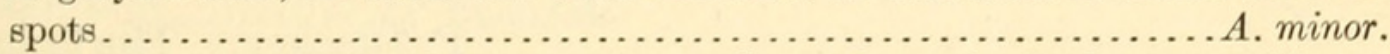

$b^{2}$. Palatine teeth in quite short rows (extending only as far back as penultimate vomerine teeth), those of outer row much larger than inner; D. 70-77; A. 43-48; color dark gray, on back and sides manifest in darker cross bands (9-12) and on shoulders in darker spots........................... lupus.

$a^{2}$. Dorsal spines $81 \mathrm{pm}$; vomerine teeth notably extending forward beyond palatine (by nearly 2 pairs), foremost with mammiform crowns, hindmost flattish convex; palatine teeth in outer row erect and conic or with mammiform crowns (extending as far back as centers of last vomerine teeth), those of outer row larger than inner; color dark brown, without bands or spots................ lepturus.

\section{ANARRHICHAS MINOR.}

Anarrhichas minor Olafsen, Reise i Island, 1772, p. 592 (Iceland). Anarrhichas pantherina Zuiew, Nova Acta Petropol., vol. 5, 1781, p. 271, pl. 6. Anarrhichas karrak Bonnaterre, Encycl. Ich., 1788, p. 38. (After Olafsen.) Anarrhichas maculatus Bloch, Syst. Ich., Schneider ed., 1801, p. 496. (After Olafsen.)

Anarrhichas leopardus Agassiz, Pisc. Brasil, 1829. (Atlantic Ocean.) Anarrhichas eggerti Steenstrup, Forh. Naturf., 1842.

North Atlantic, in deep water, south to Scotland and Maine. 
ANARRHICHAS LUPUS.

Anarrhichas lupus Linneus, Syst. Nat., 10th ed., 1758, vol. 1, p. 247. (Northern seas.)

Anarrhichas strigosus Gmelin, Linn. Syst. Nat., 1788, vol. 1, p. 1144. (British seas.)

Anarrhichas vomerinus Agassiz, Storer, Mem. Amer. Acad. Arts and Sci., vol. 5, p. 265 .

North Atlantic along the shore of Europe to British Channel and of America to Cape Cod.

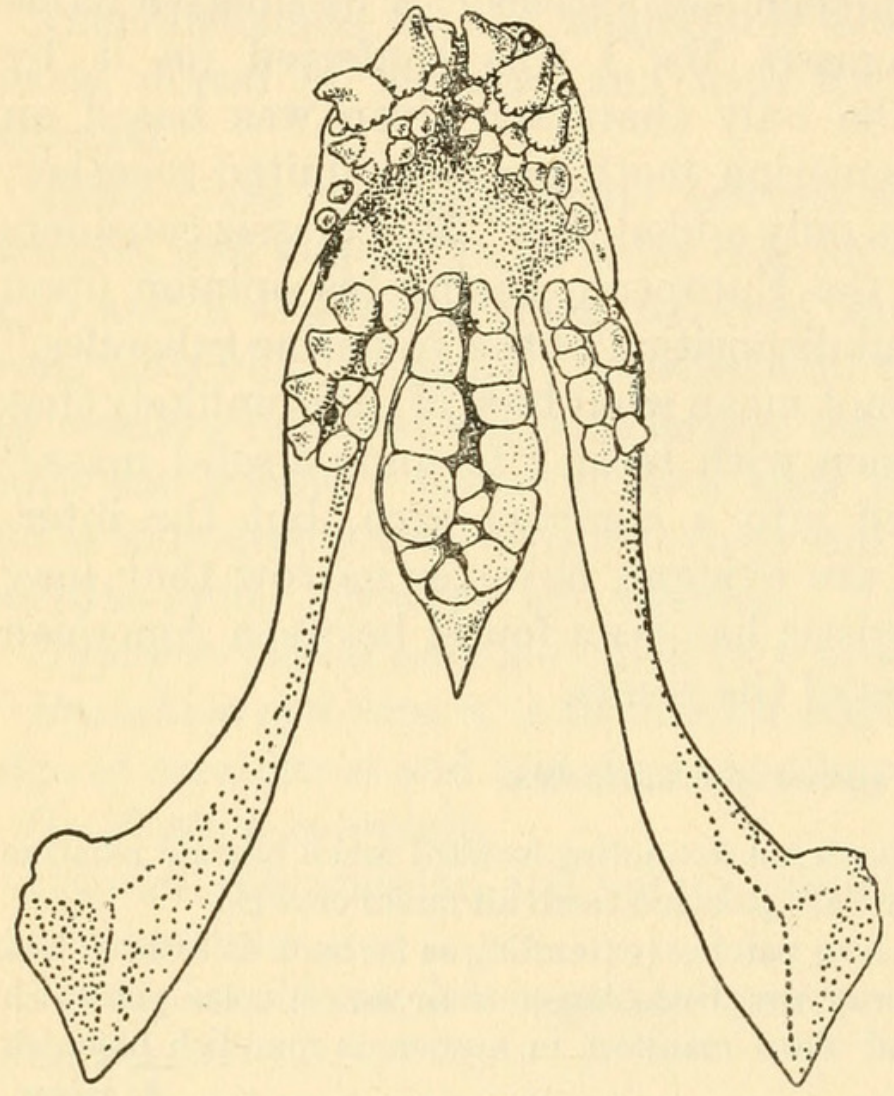

Fig. 11.-ANarRhichas lupUS, UPPER teeth.

\section{ANARRHICHAS LEPTURUS.}

Anarrhichas lepturus BEAN, Proc. U. S. Nat. Mus., vol. 2, 1879, p. 212. (St. Michaels, Alaska.)

North Pacific south to Vancouver Island; common around the Aleutian Islands.

\section{ANARRHICHAS ORIENTALIS.}

Anarrhichas orientalis PaLlas, Zoograph. Rosso-Asiatica, vol. 3,1811, p. 77. (Kamchatka.)

Coast of Kamchatka.

Another nominal species of a very doubtful character is one known only from a Chinese figure and named Anarrhichas fasciatus by P. Bleeker. The figure was one of many (462) paintings by Chinese artists, collected by J. Senn van Basel and deposited in the museum of the University of Gröningen. The drawings of fishes (440) were examined by Dr. P. Bleeker and a number of supposed new species described from them. One of these was the $A$. fasciatus, of which nothing was known as to habitat or habits, and nothing further can be known until specimens are obtained. The descriptive notice of the figure was published in $1873^{a}$ and here follows:

\section{Anarrichas fasciatus Blkr.}

Corpus altitudine $5 \frac{3}{5}$ circ. in ejus longitudine, viridescens, fasciis 14 circ. transversis profunảe viridibus spatiis intermediis latioribus, pinnam dorsalem intrantibus. Operculum macula rotunda nitente viridi vel coerulea. Caput, dorsum lateraque insuper coerulescente et rubro arenata.

\footnotetext{
$a$ Nederlandsch. Tijdschrift voor de Dierkunde, vol. 4, p. 151.
} 


\section{Genus ANARRHICHTHYS.}

Anarrhichthys Ayres, Proc. Cal. Acad. Nat. Sci., vol. 1, 1855, p. 32.-Girard, Expl. and Surv. for R. R. route to Pacific Ocean, vol. 10, Fishes, 1858, p. 124. Type.-A. ocellatus Ayres.

Anarrhichadids with the body greatly elongated and tapering backwards into a very long and compressed tail terminated by a caudal fin of normal type but much reduced in size; rudimentary scales, dorsal fin elevated (about twice as high as the anal) and graduated to caudal; without enlarged hinder spines.

Teeth more or less blunt; intermaxillary very robust, especially foremost, about 6 in an outer row, small and irregular in an inner row ; mandibular 4 large in front with moderately blunt tips, crowded and molar on sides, the ridge

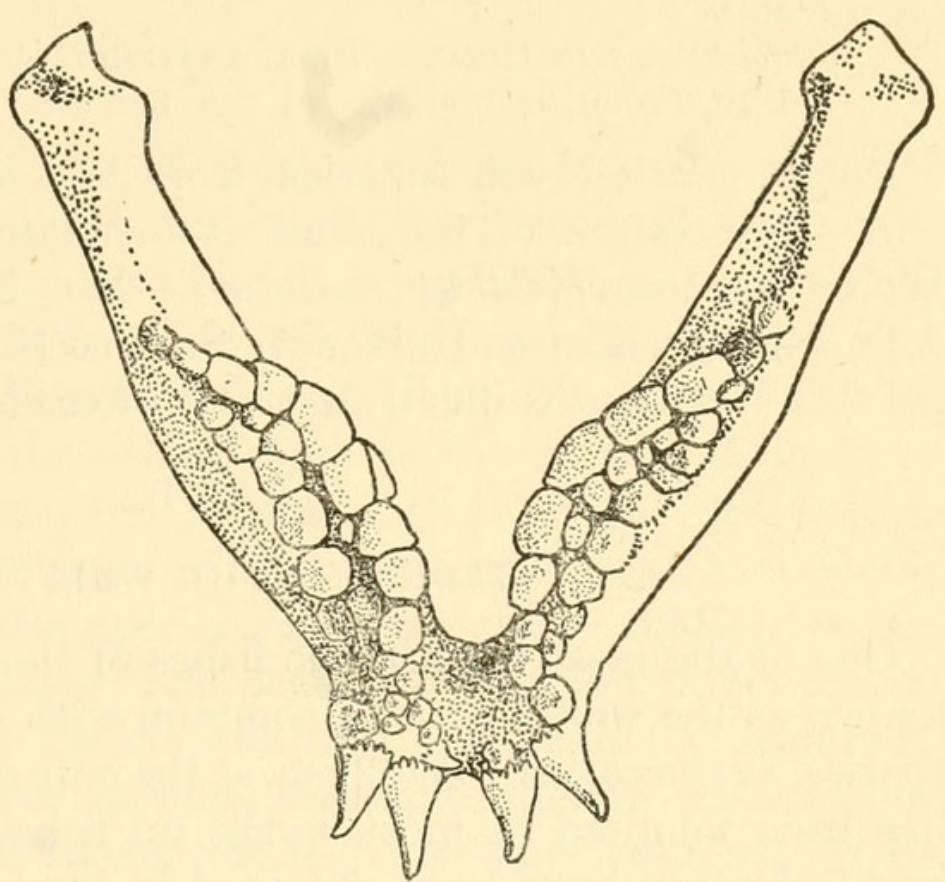

Fig. 12.-ANarrhichas lupUs, Mandibular teeth.

of the dentary inflected and with largest teeth, those of the inner row smaller and irregular; vomerine in a wide patch longer than palatine, molar and closely crowded in two rows only; palatine molar, crowded and imperfectly biserial.

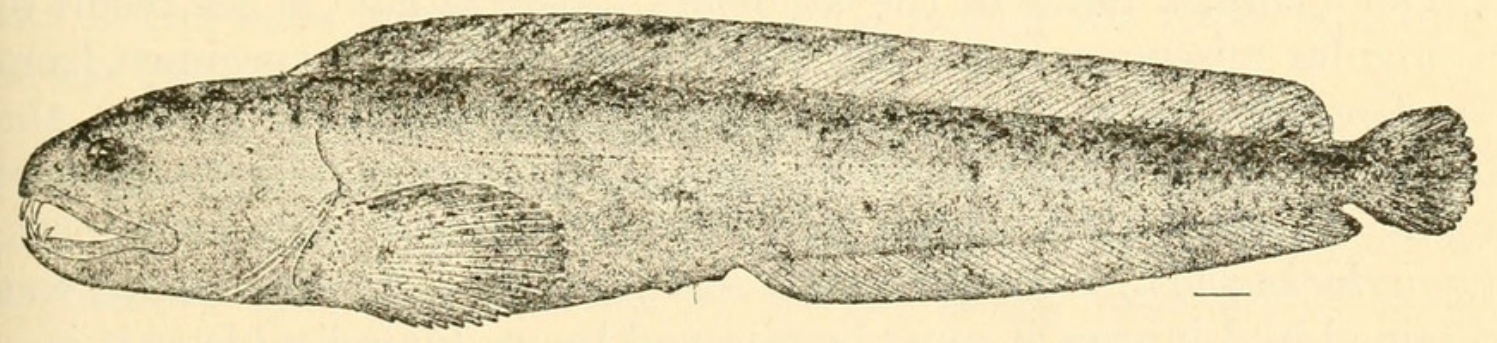

Fig. 13.-ANARRHICHIS LePtURUS (AFTER TURNER).

Hypopharyngeal teeth rather slender, but blunt and irregularly biserial.

Branchiostegal rays 8, 4 to inferior edge of ceratohyal, 2 to hinder edge of ceratohyal, and 2 to upper surface of epihyal.

Cranium with ossification complete, but frontal and ethmoid spongious; the cranial axis nearly rectilinear, the vomer being but little extended below the axis; parasphenoid much compressed, narrow in front of cerebral chamber; post frontal region much compressed 
and very narrow and sharply carinated between interorbital region and supraoccipital.

Actinosts (second and third) almost square and not constricted at middle.

\section{ANARRHICHTHYS OCELLATUS.}

Anarrhichas felis Girard, Proc. Acad. Nat. Sci. Phila., vol. 7, 1854, p. 150. (Not described.)

Anarrhichthys ocellatus Ayres, Proc. Cal. Acad. Nat. Sci., vol. 1, 1855, p. 31. (San Francisco.)

Anarrhichthys felis GIRARD, Expl. and Surv. for R. R. route to Pacific Ocean, vol. 10, Fishes, 1856, p. 125, pl. 25a, figs. 1-3.

Pacific coast, North America, from Alaksa to Monterey.

A "description of the skull and separate cranial bones ${ }^{a}$ of the Wolf-eel (Anarrhichthys ocellatus)" has been published by L. A. Adams in the Kansas University Science Bulletin (vol. 4, Sept., 1908, pp. 331-355) and is illustrated by 12 excellent plates (25-36).

PART 2.

\section{HABITS OF THE WOLFFISHES.}

One of the most remarkable fishes of the northern Atlantic is that known as the wolffish, or, in common with many other very different species, as the catfish. Wolffish, as the only distinctive name, naturally has been adopted in most works on fishes. Many data respecting its life history have been obtained in recent years, but above all by the investigators connected with the "Fishery Board for Scotland." Such are scattered through many volumes and are for the first time collected in the present article.

\section{I.}

The technical name of the wolffishes (Anarrhichas) is the result of a singular misconception. Konrad Gesner received a specimen from the German Ocean and was told (or thought he was told) that the fish climbed out of the water on the rocks; consequently he devised

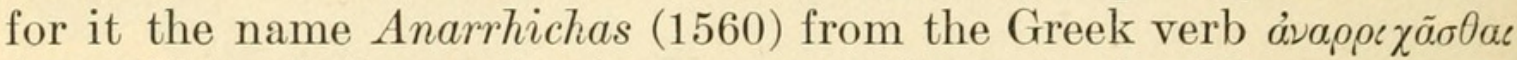
(anarrhichasthai), to clamber or scramble up. As this name was retained by Linnæus it must be retained by us, inapplicable as it is.

The most common vernacular names are wolffish and catfish. Wolffish is given with reference to its enlarged pointed front teeth and savage disposition and is the one adopted in most works on fishes. Catfish (given partly with reference to the teeth and partly in allusion "to the somewhat cat-like form of its large rounded head") is likewise in quite general use-more than wolffish, indeed-especially along the eastern coast of Scotland and the New England coast (Massachusetts, etc.). Seawolf amd seacat in some localities are used instead.

$a$ The opercular, branchiostegal and branchial systems are not described or figured. 
Wauffs or wuffs, accredited to Yorkshire, are evidently provincialisms for wolves. Equivalent terms are wolffisch, seewolf, and wolffisch of the Dutch, Søulv and Ulvfisk of the Danes, and Loup marin of the French. The Swedes prefer the analogy to the cat (Hafkatten or seacat). In Orkney, swinefish is in vogue, and allusion thereby, according to Day, ${ }^{a}$ is made to "a sort of muscular motion of its nostrils which the fishermen say resembles that in the nose of a swine." In Norway its current name is Steenbider or Stonebiter.

II.

The wolffishes are inhabitants of cold and moderately deep water of the Northern Hemisphere, but in varying degrees, according to species. In the Atlantic, the common species (A. lupus) at times approaches shallow water and sometimes even is left in tide pools, as in the Bay of Fundy and along the coast of Maine at Eastport, where the tides are abnormally great; on the other hand, as Goode and Bean have truly remarked, farther south "on the New England coast it is frequent in the deep waters" and "is associated with many deep-water forms." The other Atlantic species never goes into shallow water; the spotted wolffish (A. minor) has been found as low down as 200 fathoms at least. In the Pacific one of the species (A. lepturus), more even than the A.lupus, ascends into quite shallow water. The common wolffish, however, seems not to be entirely confined for its whole life to a particular locality. ${ }^{b}$ There is, it has been claimed, a partial migratory movement from deep water into shallow and the reverse. According to T. Wemyss Fulton (1903), there "appears to be a migration of the large catfishes from the deeper water shorewards in winter and spring for spawning." This being effected, a limited reverse movement takes place. ${ }^{c}$ Small individuals are rarely taken and it has been assumed that such hide among the rocks and thus escape capture.

As in the depths, where darkness ever reigns, it is always night, so in the night the common wolffish in shallow waters is most at home and most active. The habits of some, confined in the Manchester Aquarium, specially observed by Saville Kent, were found to be "essentially nocturnal, the fish remaining perfectly quiescent through-

$a$ Low (George) in his Fauna Orcadensis (1813), was the first to publish the data in question.

$b$ According to J. Epton, of Grimsby (in Herbert (editor), Fish and Fisheries, 1883, p. 248), "it chiefly inhabits the northernmost side of the Doggerbank, in depths of 17 to 45 fathoms. This fish does not appear to roam about."

$c^{c}$ The Alaska wolffish (A. lepturus) is especially declared by Turner (1886) to be "a migratory fish, coming to the shores at Saint Michael's as soon as the ice leaves the beach. It remains until ice forms in November. During the period between those dates it is quite plentiful. It frequents the rocky ledges, shelves, and points which have vegetation growing near the edge of the water." 
out the day on the shingle at the bottom of their tank, but arousing from their lethargy and swimming about in search of food on the approach of night." The Alaskan wolffish (Anarrhichas lepturus) is also well known to the Eskimos to be "mostly nocturnal in its habits," and is generally caught during night.

A favorite attitude of rest is to lie "with the body doubled up." A spot by the side of a rock or in a rocky recess is chosen when it can be had. If seaweeds abound about its lurking place it is so much the more acceptable. If such are not readily accessible, however, the bare ground may afford a resting place.

Its natatory movements are said to be much like an eel's, although of course less sinuous on account of its stouter form; according to Smitt "the long soft body, tapering tail, and small caudal **** probably render it a poor long-distance swimmer. Its movements, too, are slow."

\section{III.}

Old writers gave the wolffish a very bad character. Lacépède charged that, "cruel as the shark, it works terrible havoc among its own kind, and displays the same voracity in the piscine world as the wild beast from which it derives its name, among the defenceless herds." Doubtless the fish's aspect as well as name led to the inference. The structure, however, is not adapted for piscivorous habits. The strong and projecting front teeth are chiefly used and are efficient for picking or raking out from their coverts the shells, crabs, and echinoderms lurking therein; the array of grinding teeth in the roof and sides of the mouth for crushing them. ${ }^{a}$ The powerful teeth and jaw muscles, while not the best armature for a fish-eating animal, are admirably adapted, some for collecting, others crushing, shells. "Of the power of the jaws," says Smitt, "one may convince oneself by opening the stomach, which may be chock-full of crushed thick-shelled mussels and other shellfish. It eats them in great quantities, and the thin-walled intestine is often full of thin shells." One of the earliest observers (Bellamy in 1843) found "the stomach contained small crabs, Pecten opercularis, Fusus corneus, etc., all fractured by the conical and flat sets of teeth prior to being swallowed." But large drafts are also made on the thinner-shelled crustaceans. According to W. Ramsay Smith (1890), "in the Firth of Forth arthropods (Eupagurus, Hyas, Portunus, Nephrops, Crangon, Gala-

a A comparison of the conchifragous Sciænids of America (Pogonias chromis and Aplodinotus grunniens) is interesting as showing how the same function (shell-crushing) may be effected in quite different ways. In the wolffishes the shells are crushed as soon as they enter into the mouth by the side teeth of the jaws and palate; in the drumfishes the jaws have no crushing teeth, and the palate no teeth at all, but the pharyngeal bones (hypopharyngeal and middle epipharyngeal) are enlarged (the former consolidated) and paved with huge molar teeth. 
thea)"-that is, crabs, hermit crabs, lobsters, and shrimps-"were found in about 50 per cent" of the wolf- or "catfishes" caught in 1889; "sandstars and molluses were found each in about 30 per cent," and "annelids and fish as articles of food were merely represented."

Fulton (1903) examined eight fishes caught in the Moray Firth in May, 1902, and found, besides crabs and shells, many brittle-stars (ophiurids) and, in one fish, "a specimen of Aphrodite aculeata [an annelid worm] and a fragment of a zoophyte."

Verrill (1871) found in the stomach of a large fish caught at Eastport, Me., "at least four quarts of the common round sea-urchin (Euryechinus drobachiensis), most of them with the spines on and many of them quite entire." From another he took "an equal quantity of a mixture of the same sea-urchin and the large whelk (Buccinum undatum). Many of the latter were entire or but slightly cracked." It would thus appear that the crushing apparatus of the fish is not called into requisition as often as might be expected, but, in the stomach of one mentioned by Buckland, "nearly two pints" of crabs had been ground "up to mince meat."

Observations made in 1903 by R. A. Todd ${ }^{a}$ corroborated the shellfish diet of the wolffish. In the stomachs of six individuals no fishes were found. The contents were shellfishes (scallops, etc.), crabs, hermit crabs, and echinoderms. In fine the food depends very much on what it can find for the time being, with instinctive preference for that which can be crushed.

A habit of an Alaskan wolffish (Anarrhichas lepturus) has been indicated by L. M. Turner (1886) which has not found a parallel observer for the corresponding Atlantic form. "The strong [front] teeth are used to tear the sods of grass that may wash into the sea from the shore or cliff ledges into pieces to eat." His "attention was once directed to a floating sod, a short distance from the shore, going through strange motions." A native informed him that it was a wolffish and he "directed the canoe toward the sod and saw the fish tearing it. It was with difficulty that" the fish was made to "leave its food, and only after several thrusts at it with the paddle did it swim off." The natives, it seems, also catch the fish "with hooks baited with grass roots." It is probable that such assaults upon vegetable masses are for obtaining the crabs and shells lurking in them rather than for the plants themselves.

Smitt asserts that a wolffish "apparently leaves its companion fishes in peace, being perhaps of too sluggish temperament to trouble them." W. R. Smith (1892) found remains of fishes in only two wolffishes out of twelve examined, herrings in one case and unidenti- 
fied in the other. It indeed mangles fishes caught with it in a net, but it does so in unreasoning wrath and not for food.

That organization which so well fits the fish for a conchifragous habit, however, renders it capable of inflicting severe injuries on fishes and even man, if occasion provokes or requires. Conscious of its power, it disdains to flee, and will even attack one who intrudes on its near neighborhood. Goode tells that it is "pugnacious in the extreme" and has been "known to attack furiously persons wading at low tide among the rock-pools of Eastport," Maine. In Olsen's Piscatorial Atlas of the North Sea (1883) "divers are warned not to meddle with this fish in the water, or he will be sure to make an attack." It may in fact bite at any object presented to it.

The wolffish's strength of jaw and tenacity of hold are remarkable. Buckland relates that the smaller of two fishes caught in a trawl "on being brought on deck bit at a mop handle which was held out to it so savagely that it was swung overboard without letting go its hold. When it was shaken off, one of its teeth was left behind it fastened in the wood." A full-grown fish, it is claimed, "can snap a broom handle in two with the greatest ease." Steller saw a knifeblade readily broken by one.

\section{IV.}

Sexual maturity may be attained by the common wolffish when a length of not much more than 2 feet (possibly less in exceptional cases) has been attained, but generally spawners are considerably larger. Fulton (1890) examined 59 specimens of completely "ripe fish" and the smallest was 27 inches long, while the largest was 42 inches. The average length of the 59 was nearly 3 feet (34.8 inches).

The relative proportion of the sexes seems to be somewhat exceptional. According to the expressed opinion of some naturalists, and the recorded observations of 59 specimens by T. Wemyss Fulton (1890), the males appear to be not only larger but more numerous than the females. Of the 59 examined by Fulton 33 were males and 26 females; the average length of the former was 29.4 inches and of the latter only 27.6 inches, the females being thus only $87 / 100$ as large as the males. The general impression was later expressed by M'Intosh and Masterman in the statement that "the females are smaller in size than the males and are in a slight minority."

Fulton, as late as 1905, considered that the spawning season of "the common species has not yet been well determined," but that "M'Intosh and Masterman are probably right in supposing that the main spawning time of this fish is from November to January, with a margin on either side." At any rate, it is deferred till the commencement of cold weather or winter. Mature eggs were found, however, in one fish caught as early as the "6th August," in 1904, but this case was quite exceptional. 
The ovaries present some noteworthy characteristics which were long ago noticed by W. C. M'Intosh (1885) and contrasted with those of the so-called "viviparous Blenny" or Zoarcid. "In shape these considerably differ, since they are separate anteriorly and connate posteriorly, as usual in many fishes. Their walls are also much more massive. There is considerable similarity, however, in the arrangement and connexion of the ova with the ovarian wall, to which they are fixed like large flattened bunches of grapes." "In a female procured during the trawling experiments at the end of August [29th, 1884], the majority of the ova were about 4 millim. in diameter, each being attached by fine thread-like bands of tissue. The membranous parts of the folds to which the ova were attached show, in addition, numerous microscopic ova. The vascularity of this tissue is slight, and in striking contrast with the villous processes in the ovary of the viviparous Blenny. The ovaries of a specimen obtained in February were unusually coarse internally from the presence of numerous large ova ( 5 millim. in diameter) amongst the smaller. Some of the large ova were quite free and apparently ready for extrusion, while others were fixed to the membranous pedicles and folds, which presented many branching blood vessels, as well as more minute ova. The latter seem to be developed everywhere in the stroma" or indifferent tissue "of the ovary and its villous processes. From the variable size of the ova in this instance, the spawning period probably extended over a considerable time. The ova are, further, evidently deposited in the bottom." "In other examples the nearly uniform size of the majority would show that many are deposited simultaneously." In the ovaries of a fish examined "on 28th May," 1890, T. Wemyss Fulton (1891) also found "the great mass consisting of ova of nearly uniform size ( 2.1 to $2.5 \mathrm{~mm}$.). Along with these there were a large number of ova much more minute $(0.8$ to $0.9 \mathrm{~mm}$.) scattered in the interstices." Further, Fulton found "a large, fully matured ovum (the only one present), much more pellucid than the others $(6.1 \mathrm{~mm}$. in diameter), and weighing exactly 1.5 grains." $\mathrm{He}$ "considered it a good example of what occurs in the development of the eggs in many fishes - a more or less gradual growth up to a certain point, and then a sudden expansion. The medium-sized ova had apparently begun to undergo this process preparatory to extrusion. There were a few (but very few) intermediate in size between the latter and the more minute ova, which no doubt served for a second crop. Sixty grains were weighed and counted; they contained 431 large ova and 321 of the very minute ones; so that the total number present in the ovaries would be-large, 14,388 ; small, $10,682=25,070$." The number of eggs thus estimated may be much greater, the number depending on the size of the fish. A large female, according to M'Intosh and Masterman, "may produce as many as 40,000 eggs."

Proc.N.M.vol.39-10-14 
The eggs are of "the demersal type" and are "deposited in large masses by the female amongst the rocks and weed of the shallow waters. Like most demersal types, they cling firmly together by reason of a secretion extruded from the parent. They only adhere at limited parts of the egg-capsule, so that aeration through the mass is easily effected. Their deposition in large masses doubtless facilitates their fertilization by the male. In size they closely approximate those of the salmon; and indeed until quite recently," in spite of the localities in which they are found, "they were commonly mistaken by fishermen and others for those of the latter fish." The eggs are nearly a quarter of an inch (" 5.5 to $6 \mathrm{~mm}$.," or even slightly more) in diameter, "the largest marine demersal egg with which we are at present acquainted," though much smaller than the eggs of certain marine catfishes (Tachisurines) and fresh water Osteoglossids which the males carry in their mouths.

\section{V.}

Eggs, probably deposited in December, were hatched near the end of January, and the newly hatched larvæ were nearly half an inch ("12 mm.") long, "the largest British marine Telostean larva yet described." These larvæ were contrasted by M'Intosh and Masterman with those of salmon of the same stage. The yolk and contained oil-globule is of inconspicuous color and the yolk-sac spheroidal; there is but one large oil-globule which is anterior in position; the snout is very blunt and the eyes foremost; the marginal fin is continuous.

Development proceeds rather slowly; in some the absorption of the yolk may be delayed and "the larval period may thus continue till the end of June," but in others "may terminate at the middle of May." Thereafter it grows more rapidly. "In 6 or 7 months-for example, in July - its length may be 6 inches, and the following February," when about a year old, "from $8 \frac{1}{2}$ to 10 inches. In its second year it may grow to a length of 18 or 20 inches." Maturity is probably attained during its third year, but growth may continue slowly for years afterwards.

Young less than an inch long (.75-.80) have been found from February to May, "showing," according to M'Intosh (1890) "that the escape of some of this species from the egg must take place at the beginning of the year. "On 11th July a specimen $6 \frac{3}{8}$ in., 5th August another $7 \frac{3}{8}$, and on the 27 th of the same month, a third $8 \frac{1}{4}$ in. were obtained" and noticed by M'Intosh (1886). These undoubtedly were of the first year's growth. Those from 14 to 18 inches long; caught in summer, are fishes of the second year's growth. During the third year the length of 2 feet or more may be reached and sexual maturity attained. Growth, however, may not cease for years, and 
it has been claimed - as by Günther (1880 and 1886) - that "a length of more than six feet" may be realized, ${ }^{a}$ but no such instances have been recorded within recent years. The old statements (as by Gronow and Lacépède) $)^{b}$ that a length of 15 or 16 feet is sometimes attained may be relegated to the category of fable.

\section{VI.}

The almost universal testimony of those who have been able to conquer the prejudice provoked by the appearance and odor of the fish, is that the common wolffish is one of the most savory of the inhabitants of the sea for the table. "The meat is white, firm, and of a fine flavor." It has been repeatedly declared to be "excellent eating." Buckland (1880) considered it to be "very good" and "like a nice veal chop." Donovan (1803) found that cooking eradicates its unpleasant odor, and then it is "delicious" and somewhat like a mackerel, but better. Fishermen generally regard it highly and some think "it is the best fish that swims." The fishermen of Bohuslän regard it as "a good catch, and its liver in particular as a delicacy." But in many places, and in America especially, most persons are repelled by the forbidding appearance of the fish as well as by the smell "which is highly repulsive to most people." In America, in the words of Storer (1855), "its hideous appearance renders it an object of such disgust that it is not infrequently thrown away as soon as caught. By many of our fishermen, however, it is considered very delicate; the smaller specimens weighing from five to ten pounds, are quite palatable when fried, boiled, or broiled, the skin having been previously removed. It is also occasionally split and salted, or dried, or smoked, and is said to be, when thus prepared, very good." It is, nevertheless, only exceptionally to be found in any market.

$a$ Yarrell, in 1836 (I, p. 250), affirmed that "this fish attains the length of six or seven feet", [etc.]. This has been often repeated since. Olsen, in his Piscatorial Atlas of the North Sea (1883), gives the "size, 3 and $4 \mathrm{ft}$. up to $7 \mathrm{ft}$.," with the "weight 20 to 50 lbs." Goode, in 1884, also recorded that "the largest individuals of this species are 6 or 7 feet in length and would probably weigh 40 pounds. The specimen mentioned by Richardson, 3 feet long, weighed 20 pounds." If a fish 3 feet long weighed 20 pounds, one double that length, if the same proportions were preserved, would weigh eight times as much-i. e., 160 pounds.

$b$ Ce poisson peut figurer avec avantage à côté du Xiphias, et par sa force, et par sa grandeur. Il parvient quelquefois, au moins dans les mers très-profondes, jusqu'à la longueur de cinq mètres; [etc.]. Lacépède, vol. 2, p. 300.

Valenciennes, as early as 1836 (CV. XI, 488), well summarized the facts as to size: "L'anarrhique a ordinairement trois à quatre pieds; tous les auteurs qui l'ont observé par eux-mêmes ne lui donnent pas une longueur plus considérable et un poids supérieure à vingt livres. J'ai peine à croire à celle de quinze pieds, annoncée par Gronovius pour ceux des mers du Nord, et répétée avec tant d'emphase par M. de Lacépède."' [etc.]. 
In England sometimes the flesh is colored with anatto. A. H. Patterson ${ }^{a}$ saw some prepared for market at Great Yarmouth cut into "rich yellow sections" looking "uncommonly like filleted haddocks, the colouring being much more ochreous, and the general appearance exceedingly appetising." They sold well so dressed and a piece cooked like haddock was found "fairly good eating, slightly 'twanging' of a skate-like flavour."

Equally worthy of esteem with the Atlantic wolffish are the spotted and Alaskan wolffishes. The deepest-water species or blue wolffish is, however, with one accord, rejected by all. That species, according to Sparre Schneider, is regarded as uneatable by "even the Russians," but a few are utilized by being "flayed and hung up to dry" for their skins.

It is not only the flesh of the wolffishes that is utilized by man. The skin is also appropriated to his use in some places, and, as just noted, even that of the blue wolffish (Lycichthys latifrons), which is contemned for its flesh, may be accepted for economical purposes. According to Smitt, "not only the flesh," of the common wolffish, "but also the strong skin is of comparatively high value." Smitt, however, does not give any information as to the mode of utilization of the skin.

The skin of the Alaskan wolffish (A. lepturus) is equally valued. Turner (1886) says that "the natives strip the skin from this fish and tan it, to be used in inserting between the seams of boots and other waterproof garments. The skin of the fish is said to swell when moistened and thus draw the threads tighter together. The dried skin is totally different from the fresh skin, in that it is nearly black and beautifully mottled with black and silvery dots."

Partly because there is no general demand for it, and partly because it is a solitary fish and not very common, there is no extensive or exclusive special fishery for the wolffish in any country.

Individuals are elsewhere often taken by lines set for cod and haddock, and sometimes in salmon nets in estuaries. A notable mode of capture is practiced for the Alaskan wolffish at St. Michaels. "The Eskimo bait a large hook with tender grass roots and cast it into the water when the tide is at half-flood in the evening, as the fish is mostly nocturnal in its habits. The part of the line near the hook is usually made of a stiff strip of baleen to prevent the numerous teeth of the fish from cutting the line in two."

The most extensive captures are by the trawl. The most reliable and comprehensive statistics of catches of the wolffish or catfish have been published by the Board of Agriculture and Fisheries in their annual reports. In the Annual Report of proceedings under acts 
relating to sea fisheries for the year 1907 (1909, pp. xxiv, xxv, lxxxiv, $\mathrm{lxxxv}$ ), it is declared that "catfish are entirely confined to the northern regions and the North Sea and are taken almost entirely by steam trawlers." A total of 74,150 hundredweight were landed in Great Britain in $1907 ; 23,234$ hundredweight were taken in the North Sea, 28,958 hundredweight were brought from Iceland, 18,434 hundredweight were received from Faroe, and 2,214 hundredweight came from as far as the White Sea. The rest were caught chiefly around Scotland. These proportions of course vary greatly from year to year. The quantity landed is greater than that of such esteemed fishes as the turbot and sole. ${ }^{a}$

The wholesale as well as retail price greatly varies. In the Bulletin Statistique, published by the Conseil Permanent International pour l'Exploration de la Mer (1906), figures are given for Germany, England, and Scotland for 1903 and 1904. In 1903 the wolffish commanded in Germany, for a kilogram (about $2 \frac{1}{5}$ pounds), an average price of 0.20 of a shilling, and in 1904, 0.17 of a shilling; in England, respectively, 0.17 and 0.11 of a shilling, and in Scotland (1904), 0.11 of a shilling. The price was approximately equal to that realized for whiting in England and Scotland and much more than that prevailing for the same fish in Germany. It was considerably greater than the price obtained for herring in the same years in England and Scotland, but less than that commanded in Germany.

\section{HABITS OF THE WOLF EEL.}

The wolf eel (Anarrhichthys ocellatus) is pronounced by Jordan and Evermann (1898) to be "one of our most remarkable fishes." "Wolf $e e l$ " is a made name originating from some one acquainted with the wolffish. A more common designation along the Pacific coast, where the true eel was unknown until introduced, is eel. According to Jordan (1884), also, 'the name 'Agia' is given to it by the Dalmatian fishermen on Puget Sound, and that of 'Morina' by the Italians at Monterey." There may be some misunderstanding as to Agià, for in the Adriatic and along the Dalmatian coast the name Azià, (also spelled Asià, Asiao, and Asiar,) is applied to the piked dogfish (Squalus acanthias). Morena (not Morina) is an Italian name of the common moray (Muraena helena) and therefore expresses essentially the same appreciation of resemblance as the English name eel.

It is an inhabitant of the Pacific coast from Puget Sound to Monterey, "lurking among the rocks and occasionally left by the falling tide." Sometimes, but rarely, a length of 8 feet or even more is

$a 67,348$ hundredweight of the turbot and 63,085 hundredweight of the sole were landed in 1907. 
attained. "It feeds chiefly on sea-urchins and sand-dollars" (Echinarachnius excentricus), according to Jordan and Evermann. Lockington (1879) found "a very stout-looking example, 5 feet long," whose stomach was "filled with the tests of Echinarachnius excentricus, the common cake-urchin of the [Californian] coast, broken into large fragments, many of them considerably more than an inch across." Its diet, in fact, seems to be much like that of the common wolffish. "It is rarely used as food," say Jordan and Evermann (1898), but earlier (1880) Jordan had found that "as a food-fish, it meets with a ready sale." Now, as in 1880, "nothing special is known of its breeding habits, enemies, or diseases." Certainly some fish student of one of the Californian universities or laboratories should supplement this very scanty information. 


\section{BIBLIOGRAPHY.}

The following is a list of articles which have been utilized more or less for facts recorded concerning the life history of the wolffish. It has not been deemed necessary to give the titles of works in which the systematic relations or anatomy of the fish are considered. Those interested may find the requisite information or be guided to it by consulting the synonymies in the works of Day, Smitt, and Jordan and Gilbert.

In addition to the works enumerated, the various faunal works have been consulted, as also the Jahresbericht der Kommission zur wissenschaftlichen Untersuchung der deutschen Meere in Kiel (1871-1893), the Wissenschaftliche Meeresuntersuchung herausgegeben von der Kommission zur wissenschaftlichen Untersuchung der deutschen Meere in Kiel [etc.], the publications of the Conseil Permanent International pour l'Exploration de la Mer, the Meddelelser fra Kommissionen for Havunders $\varnothing$ gelser, the Reports of the Danish Biological Station, etc.; but any data published therein are mainly of local interest and relate to details of distribution which are beyond the scope of the present article.

Andre, William.-A description of the teeth of the Anarrhichas lupus Linnæi, and

of those of the Chxtodon nigricans of the same author; [etc.].

Phil. Trans. Royal Soc. London, vol. 74, 1784, pp. 274-282, pls. 11-13.

Excellent figures of the teeth of the wolffish, pl. 11.

... "The anterior sharp teeth of the sea-wolf are admirably calculated for seizing its prey, while, the posterior grinding teeth serve to break down the hard shells of lobsters, crabs, muscles, scollops etc., which this animal is known to feed upon," p. 277.

Atrinson, George T.-Notes on a fishing voyage to the Barents Sea in August, 1907.

Journ. Mar. Biol. Ass. U. K., n. s., vol. 8, 1908, pp. 71-98, pl. 4.

"Cat (Anarrhichas (minor?))," p. 96.

"Two catches, 10 and 11 fish, respectively, were measured, the range of size being 88-120 and 102-125 em. These ranges and the quantity were typical of most of the hauls in the region at this time."

Brenm, A. E.-Brehms Tierleben. Allgemeine Kunde des Tierreichs, [etc.]. Dritte ... Auflage. Herausgegeben von Prof. Dr. Pechuel-Loesche. Fische. Leipzig und Wien. Bibliographisches Institut. 1892.

Der Seewolf noticed, pp. 148, 149. (A meager account.)

Brook, George.-The spawning period of British food-fishes.

Fourth Annual Report Fish. Board, Scotland, App., 1886, pp. 242-254.

Catfish, p. 245.

Broussonet, P. M. A.-Sur le loup marin.

Hist. Acad. Sci. Paris, 1785, pp. 161-169.

Buckland, Frank.-Natural history of British fishes; their structure, economic uses, and capture by net and rod [etc.]. London, Society for Promoting Christian Knowledge, [etc., 1881].

Cat or wolffish, pp. 41-43.

Conseil Permanent International, Etc.-See International Council, etc.

Crisp, Edward.-On some points relating to the structure and mechanism of the wolffish (Anarrhichas lupus).

Ann. Mag. Nat. Hist. (2), vol. 11, 1853, pp. 463-466.

The mouth "is essentially an apparatus for crushing and breaking, not pulverizing; the form of the alimentary canal, as will be seen hereafter, not requiring this mode of preparation of the food," p. 464. 
Cuvier, George, et A. Valenciennes.-Histoire naturelle des poissons [etc.]. Tome onzième. A Paris, chez F. G. Levrault, [etc.], 1836.

Des Anarrhiques, pp. 472-494 (Valenciennes is the sole author of the volume).

DAY, Francis.-The fishes of Great Britain and Ireland. In two volumes. [London] Williams and Norgate, [etc.], 1880-1884.

Anarrhichas lupus, vol. 1, pp. 195-197, pl. 58.

Devis, Charles W.-Note on the wolffish.

Zoologist, 1865, p. 9558.

Front teeth noticed as "strong sharp grapplers," etc.

Donovan, Edward.-The natural history of British fishes, [etc.]. In five volumes. London: printed for the author, [etc.], [1802-]1808.

"A narhichas lupus var.?", text (unpaged) to pl. 24, vol. 1.

Ehrenbaum, E.-Eier und Larven von Fischen.

Nordisches Plankton, herausgegeben von Prof. Dr. K. Brandt and Dr. C. Apstein in Kiel [etc.]. Vierte Lieferung, 1905 (title, cover+11-216+iii pp.).

Anarrhichas, pp. 91-93.

\section{Die Fische.}

Fauna Arctica. [etc.]. Unter Mitwirkung zahlreicher Fachgenossen herausgegeben von Dr. Fritz Römer und Dr. Fritz Schaudinn. 2er Band, 1901, pp. 65-168.

Anarrhichas, pp. 95-96.

Evermann, Barton Warren.-See Jordan, David Starr, and Evermann.

Ewart, J. C., and T. Wemyss Fulton.-Report on the spawning of the British marine food fishes.

Seventh Annual Report Fish. Board Scotland, part 3, 1889, pp. 186-221.

Catfish, pp. 197, 212.

Fulton, T. Wemyss.- The distribution of immature sea fish, and their capture by various modes of fishing.

Eighth Annual Report Fish. Board Scotland, part 3, 1890, pp. 157-210.

Catfish, pp. 161, 162, 163, 176, 183 (vitality), 201, 204.

_ - - The spawning and spawning places of marine food fishes.

Eighth Annual Report Fish. Board Scotland, part 3, 1890, pp. 257-269.

Catfish, p. 269.

- - The proportional numbers and sizes of the sexes among sea fishes.

Eighth Annual Report Fish. Board Scotland, part 3, 1890, pp. 348-350.

Catfish, pp. 349, 350 .

- - Observations on the reproduction, maturity, and sexual relations of the food fishes.

Tenth Annual Report Fish. Board Scotland, part 3, 1892, pp. 232-243, 2 tab.

Catfish (number and relative size of sexes), p. 239 and tab. 5.

-On the growth and maturation of the ovarian eggs of teleostean fishes.

Sixteenth Annual Report Fish. Board Scotland, part 3, 1898, pp. 88-124, pls. 1-3.

Catfish referred to "C.-With demersal eggs," p. 91. fishes.

Twenty-first Annual Report Fish. Board Scotland, part 3, 1903, pp. 15-108, pl. 1 (folded map). Catfish, pp. $23,63-65,80,82,83,84,85,86,87,88,89,90,91,92,93,94,95,96,98,99$.

- - - Trawling observations.

Twenty-second Annual Report Fish. Board Scotland, part 3, 1904, pp. 13-99.

Catfish marketable, etc., p. 14. 
Fulton, T. Wemyss.-Ichthyological notes.

Twenty-third Annual Report Fish. Board Scotland, part 3, 1905, pp. 251-254.

The catfish (A narrhichas lupus): Eggs and spawning time, p. 252.

- - A review of the fishery statistics for Scotland.

Twenty-seventh Annual Report Fish. Board Scotland, part 3, 1910, pp. 29-191.

Catfish catches, pp. 157, 162, 166, 169, 172, 174, 178.

Goode, George Brown.-[Heading:] The fisheries and fishery industries of the United States, [etc.]. Section I Natural history of useful aquatic animals [etc.]. Text. Washington: Government Printing Office. 1884. [Quarto, xxxIv+3895 pp. Plates lxx, pp. 277, pl. 1.]

The Wolffishes, pp. 248-250, pl. 68.

Goode, George Brown, and Tarleton H. Bean.-Oceanic ichthyology, a treatise on the deep-sea and pelagic fishes of the world, [etc.]. Washington: Government Printing Office. 1895. [Quarto, $x x x v+26^{*}-553$ pp.; xxiii $+26^{*}$ pp. +123 pl. with 417 figs.]

Anarrhichadidæ, p. 298-302, pl. 77, with figs. 269-271.

Günther, Albert C. L. G.-An introduction to the study of fishes. Edinburgh Adam and Charles Black 1880. [8vo, xvi+720 pp., 1 folded pl.]

Wolffish, p. 493, noticed as "a gigantic blenny, attaining to a length of more than 6 feet."

Haus, George A.-Beiträge zur Anatomie und Histologie des Darmkanals bei Anarrhichas lupus.

Internat. Monatsschr. f. Anat. u. Physiol., vol. 14, 1897, pp. 42-52, pl.

[International Council] Conseil Permanent International pour l'ExploraTION DE LA Mer.-Bulletin statistique des pêches maritimes des pays du nord de l'Europe. Volume I, pour les années 1903 et 1904. En commission chez Andr. Fred. Høst \& Fils Copenhague, 1906 [Quarto, 262 pp., 12 pl. (maps).]

Statistics on pp. 128 and 129 quoted.

Jordan, David Starr, and Barton Warren Evermann.-The fishes of North and Middle America [etc.]. Washington: Government Printing Office. 1896-1900. [Octavo, 4 "parts" (=vol.).]

Family CCII. Anarhichadidæ, pt. 3, pp. 2445-2448, 1898; pl. 346, fig. 845; pl. 347, figs. 846, 847, 1900.

Jordan, David Starr.-See Goode (George Brown).

Kent, W. Saville.-Marine and freshwater fishes of the British Islands.

Int. Fish. Exhib. London, 1883, Literature, vol. 1, 1884, pp. 73-204; also separately issued and independently paged.

Wolffish, pp. 135-136.

LACÉPÈde, B. G. E. Comte DE.-Histoire naturelle des poissons, par le citoyen Lacépède, [etc.]. Tome second. A Paris, chez Plassan, imprimeur-libraire, [etc.]. L'an VIII de la République. [4to.]

L'anarhique loup, pp. 300-308.

Lockington, W. N.-Notes on Pacific coast fishes and fisheries.

Amer. Nat., 1879, pp. 684-687.

A narrhichthys felis, p. 684 .

M'Intosh, William Carmichael.-Notes from the St. Andrews Marine Laboratory (under the Fishery Board of Scotland).-II. On the spawning of certain marine fishes.

Ann. Mag. Nat. Hist. (5), vol. 15, 1885, p. 429-437, pl. 16.

Ovaries of the catfish, A narrhichas lupus, p. 432. 
M'Intosh, William Carmichael.-Report of the marine laboratory, St. Andrews. No. II, June, 1884, to 31st March, 1885.

Third Annual Report Fish. Board Scotland, App., pp. 55-67, 1885.

Catfish ova and ovary, p. 58.

- Report of the St. Andrews Marine Laboratory, No. III, from 1st April, 1885, to 31st December, 1885.

Fourth Annual Report Fish. Board Scotland, 1886, App., pp. 201-218.

Catfish, p. 213.

-- - Report of the St. Andrews Marine Laboratory, No. IV, from 1st January, 1886, to 31st December, 1886.

Fifth Annual Report Fish. Board Scotland, 1887, App., p. 354.

Catfish ova, pp. 356, 357.

Garland.

Eighth Annual Report Fish. Board Scotland, part 3, 1890, pp. 283-289.

Catfish, pp. 286, 288

- - The resources of the sea as shown in the scientific experiments to test the effects of trawling and of the closure of certain areas off the Scottish shores. [etc.]. London: A. J. Clay and Sons, [etc.], 1899. [Octavo, xvi+248 pp., 32 tab., 18 pls.] Catfish, pp. 52, 175, tab. 6, 7, 10, 11, 12, 13, 15, 17, 22.

M'Intosh, William Carmichael, and Arthur Thomas Masterman.-The lifehistories of the British marine food-fishes. London: A. J. Clay and Sons, [etc.]. 1897. [Octavo, $\mathrm{xv}+516 \mathrm{pp}$., col. front. $+20 \mathrm{pl}$.]

Wolffish, pp. 200-205, pl. 1, fig. 17; pl. 8, figs. 1, 2.

M'Intosh, William Carmichael, and E. E. Prince.-On the development and the life histories of the Teleostean food and other fishes.

Trans. Royal Soc. Edinburgh, vol. 35, 1890, pp. 665-946, pl. 1-28.

A narrhichas lupus, pp. 874-928, pls. 21-27.

Olsen, O. T.-The piscatorial atlas of the North Sea, English and St. George's channels. [etc.]. Illustrating the fishing ports, boats, gear, species of fish (how, where, and when caught), [etc.]. Grimsby: O. T. Olsen, [etc.] 1883. [Folio, 4 p. 1., 50 maps.]

Wolf or cat fish, map, p. 25.

Patterson, Arthur H.-Some fish notes from Great Yarmouth.

Zoologist, 1908, pp. 441-449.

Catfish, pp. 443-444.

Prince, E. E.-See M'Intosh (W. C.) and E. E. Prince.

Schneider, J. Sparre.-Nogle zoologiske iagttagelser fra Vard $\varnothing$ i $\emptyset$ st-Finmarken.

Tromø Museums Aarsberetning, 1882, pp. 16-34.

A. latifrons, p. 21.

Scotт, Thomas. - Observations on the food of fishes.

Twentieth Annual Report Fish. Board Scotland, part 3, 1902, pp. 486-541.

Anarrhichas, p. 500.

- Some further observations on the food
observed in the stomach of a common porpoise.

Twenty-first Annual Report Fish. Board Scotland, part 3, 1903, pp. 218-231.

Catfish, p. 220.

- - Observations on the otoliths of some teleostean fishes.

Twenty-fourth Annual Report Fish. Board Scotland, part 3, 1906, pp. 48-82, pls. 1-5 (+pls. 1B, 2B, 3B).

Catfish, p. 59, pl. 3B, figs. $40-43$; pl. 5, fig. 21. 
Smith, W. Ramsay.-On the food of fishes.

Seventh Annual Report Fish. Board Scotland, part 3, 1889, pp. 222-258.

Catfish, pp. 231, 252.

- On the food of fishes.

Eighth Annual Report Fish. Board Scotland, part 3, 1890, pp. 230-256.

Catfish, pp. 231, 244-245, 251.

- - On the food of fishes.

Ninth Annual Report Fish. Board Scotland, part 3, 1891, pp. 222-242.

Catfish, pp. 232, 235, 239, 240, 253.

.- On the food of fishes.

Tenth Annual Report Fish. Board Scotland, part 3, 1892, pp. 211-231.

Catfish, p. 229.

Smitr, F. A.-Smitt Scandinavian Fishes.-A history of Scandinavian fishes by B. Fries, C. U. Ekström, and C. Sundevall. With coloured plates by W. von Wright and text illustrations. Second edition revised and completed by Professor F. A. Smitt [etc.]. Text. Part I. P. A. Norstedt \& Söner, Stockholm [etc., 1892].

Fam. Anarrhichadidæ, pp. 231-238.

Steenstrup, Japetus.-Noget om Slaegten Søulv (Anarrhichas) og dens nordiske Arter.

Vid. Medd. fra Naturhist. For. Kjöbenhavn, 1876-77, pp. 159-202, pl.

- - Oplysning om Anarrhichas leopardus Agass.

Vid. Medd. fra Naturhist. For. Kjöbenhavn, 1877-78, pp. 109-114.

A. leopardus identified with $A$. minor.

Storer, David Humphreys.-A history of the fishes of Massachusetts. [etc.]. Cambridge and Boston: Welch and Bigelow [etc.], 1867. [Quarto, 2 p. 1., 287 pp., 39 pls.] Anarrhichas, pp. 99-100, pl. 18, fig. 1.

Turner, L. M.-Contributions to the natural history of Alaska. [etc.]. No. II. Washington: Government Printing Office. 1886.

Anarrhichas lepturus, pp. 93-94, pl. 5.

Valenciennes, Achille.-See Cuvier, George, et Valenciennes.

Verrill, A[DDISON] E[MoRy].-On the food and habits of some of our marine fishes. Amer. Nat., 1871, pp. 397-400.

Wolffish, p. 400.

Wilson, Andrew.-The Wolffish.

Nature, vol. 19, 1879, pp. 556-557.

Yarrell, William.-A history of British fishes. [etc.]. In two volumes. [etc.].

London: John Van Vorst, [etc.] 1836.

The Wolffish, vol. 1, pp. 247-250. ("This fish attains the length of 6 or 7 feet.”) 


\section{$2 \mathrm{BHL}$ Biodiversity Heritage Library}

Gill, Theodore. 1911. "Notes on the structure and habits of the wolffishes." Proceedings of the United States National Museum 39(1782), 157-187. https://doi.org/10.5479/si.00963801.39-1782.157.

View This Item Online: $\underline{\text { https://www.biodiversitylibrary.org/item/53443 }}$

DOI: https://doi.org/10.5479/si.00963801.39-1782.157

Permalink: https://www.biodiversitylibrary.org/partpdf/51975

\section{Holding Institution}

Smithsonian Libraries

\section{Sponsored by}

Smithsonian

\section{Copyright \& Reuse}

Copyright Status: Public domain. The BHL considers that this work is no longer under copyright protection.

This document was created from content at the Biodiversity Heritage Library, the world's largest open access digital library for biodiversity literature and archives. Visit BHL at https://www.biodiversitylibrary.org. 